\title{
Nutrition Behavior and Body Mass Index in Tanzania. Survey from a Cancer Prevention and Awareness Campaign in Northern Tanzania, 2019- 2020
}

Antje Henke ( $\square$ antje.henke@gmx.de)

Kilimanjaro Christian Medical Centre https://orcid.org/0000-0002-6363-9288

\section{Susann Rosenbaum}

Kilimanjaro Christian Medical Centre

Oliver Henke

Kilimanjaro Christian Medical Centre

\section{Furaha Serventi}

Kilimanjaro Christian Medical Center

\section{Research article}

Keywords: Nutrition Behavior, Sub-Saharan Africa, Cancer, Tanzania, Cancer Prevention, Obesity

Posted Date: November 22nd, 2021

DOI: https://doi.org/10.21203/rs.3.rs-1050016/v1

License: (c) (i) This work is licensed under a Creative Commons Attribution 4.0 International License. Read Full License 


\section{Abstract}

Objective: In Tanzania, cancer is becoming a major public health concern. Risk factors such as poor dietary behavior, high body mass index, physical inactivity, alcohol and tobacco consumption increase the incidence. Limited cancer treatment facilities, prevention programs, and poor knowledge of cancer risk factors and symptoms in the population contribute to late-stage presentation and high mortality rates. The objective of this study is to examine the association of lifestyle factors including body mass index (BMI), physical activity, and dietary behaviors among participants who attended three cancer prevention events in rural and urban areas in Tanzania.

Methods: A cross-sectional survey among PrevACamp- attendees in northern Tanzania between August 2019 and February 2020 were chosen. Participants were interviewed using a structured questionnaire on sociodemographic data, medical history, dietary habits, and physical activity, the body mass index was also determined.

Results: 235 participants (114 urban/ 121 rural) were included in the survey. Urban residents had higher rates of obesity $(p=0.0021)$ and less physical activity than participants from rural areas (4.63 days [SD=2.03] and 5.50 days $[S D=2.00]$, respectively $(p=0.006)$. Urban dwellers often skip their lunch and prefer to eat a snack. They use salt frequently, consume more processed meat, eat mainly starchy foods, drink more alcohol and sweetened sodas.

Conclusion: Rural women more interested in cancer prevention than men. People in rural areas are more physically active and less overweight than those in urban areas. The cause is manifold, yet they hint at a lack of health care for women and a progressing urbanization according to Western patterns.

There is an alarming high percentage of overweight among urban dwellers. Although people eat more healthy foods compared to rural populations, they tend to have a high body mass index. Physical inactivity and overweight will be a serious problem in Tanzania in the future, contributing to the risk of cancer.

\section{Background}

Poor nutrition behaviours are emerging as a major public health problem worldwide, with five leading attributes: high body mass index (BMI), low intake of fruits and vegetables, physical inactivity, tobacco use, and alcohol consumption. Indeed, these risk factors contribute to about one-third of cancer mortality worldwide [1]. Studies have shown that specific dietary components can contribute by increasing or decreasing the development of cancer [2] [3] [4].

Many low and middle income countries in Sub-Saharan Africa, like Tanzania, face a double burden of nutrition related diseases, with mal- and over-nutrition coexisting [5]. Cancer mortality rates are higher in Sub-Saharan Africa than in high-income countries [6].

In countries with routine, effective prevention and early detection programs, cancer incidence and mortality rates have declined precipitously over the last half century [7].

In Sub-Saharan Africa nutrition behaviours are in transition and following more and more a western pattern [5]. An important factor for changes in people's nutrition behavior is rapid urbanization [5].

Tackling cancer in Tanzania is in its infancy. Tanzania is one of the largest countries in Sub-Saharan Africa with increasing urbanization and a growing population of almost 60 million people. Tanzania`s urbanization is associated with profound lifestyle changes and a risk of developing overweight and obesity, poor physical activity, and poor

nutrition patterns [8] [9]. However, nutritional status is equally considered to be an important determinant of health [10]. 
The Tanzanian Ministry of Health and Social Welfare (MoHSW) implemented a National Cancer Control Strategy (NCCS) in 2013, which included recommendations for nutrition [11]. The details of the measures to be implemented remain open [11].

Cancer control strategies need to be strengthened at all levels, from prevention to diagnosis to treatment. To date, the health system is not yet fully prepared, having a total of three cancer centres located in Dar es Salaam, Mwanza and Moshi. Previous studies have also reported a lack of knowledge about cancer among health care providers and communities [12] [13] [14] [15] [16]. Education, sex, socioeconomic status, and place of residence influence disease perception and health-seeking behavior [13] [14] [16] [17] [18]. Consequently, it is important to educate health care providers and to increase awareness on cancer risk factors in communities [13] [19].

In addition, in Tanzania is an evident trend of obesity which makes the population vulnerable to get cancer and other nutrition related diseases [8] [9]. However, information about nutritional behaviour of people living in rural and urban regions is sparse [5] [20].

\section{Purpose of the study}

The objective of this study is to examine the association of lifestyle factors including body mass index (BMI), physical activity, and dietary behaviors among participants who attended three cancer prevention events in rural and urban areas in Tanzania.

This study was conducted to analyze dietary behaviors in the Kilimanjaro region. The survey focused on identifying possible differences among genders and among rural and urban areas.

\section{Methods}

\section{Context and Design}

This quantitative study is one of three sub-studies [13] [14] of a comprehensive research project named PrevACamp (Cancer Prevention and Awareness Campaign). This is a five-year-project at Kilimanjaro Christian Medical Center, supported by the international partners Mission One World and Foundation for Cancer Care (2017-2022). The goal of this project is to provide cancer education and screening in communities in northern Tanzania.

\subsection{Study setting and population}

A cross-sectional survey was chosen from August 2019 until February 2020 at three PrevACamp sites: in Kibosho (faith-based hospital), Mormella (private hospital) and Moshi Urban (faith-based hospital) among PrevACamp participants. According to the Tanzanian census of 2012, Moshi Urban had a population of 184,292 [21]. Kibosho is located in Moshi Rural with a population of 466,737 and Mormella is located in the rural Meru district with a population of 268,144 [21]. The majority of inhabitants make a living from day labor jobs, small businesses or small-scale farming [22]. Participants were recruited by loudspeaker cars, through church services and radio advertisements in the respective districts.

\subsection{Study technique}


Questionnaires were used as the data collection tool. BMI, according to the World Health Organization standard measurements, was assessed with scale and measure tape [23].

Respondents were recruited from all PrevACamp registrants using a convenience sample of just-arriving attendees.

Trained interviewers informed all potential respondents about the purpose of the study and obtained their consent. BMI measurement was provided to all PrevACamp participants above the age of 18 years. All were informed by nurses about the BMI measurement process and possible results.

BMI measurement: Before the interview started, the participant's weight and height were determined, and BMI was calculated. The result was documented and given to the patient and afterwards copied onto the questionnaires.

Questions from the validated General Nutrition Knowledge Measure (GNKQ) [24] were selected by two Tanzanian oncology and nutrition nurses at CCC. Chosen questions by GNKQ were rephrased, and additional questions were added for cultural and social adaptation into the Tanzanian setting. The questionnaire was designed in English, translated into Swahili, then back-translated by a local oncology nurse. The questionnaire was divided into three parts: Part (A) discussed socio-demographic characteristics including habits of alcohol and smoking consumption, questions about cancer or other disease history, BMI results and questions about satisfaction with the results, and food and shopping patterns. Part (B) included a nutrition assessment: questions about eating habits, such as intake of fruit and vegetables, fats, starchy foods and salt. Part (C) presented questions about physical activities.

The survey included in total 46 items: 26 closed responses (no/yes), 5 semi open responses (no/yes, if yes then open question), 8 open-ended responses, 2 multiple response questions and 5 binary questions about socio-demographic characteristics. Average interview time was 15 minutes. The questionnaires were administered by two male and three female interview-trained health care professionals.

BMI Measurement: Each person who enrolled in the BMI program was documented in a register "BMI screening book" from the Cancer Care Centre. Information recorded in the reporting form included: serial number, name of client, address, phone number and age. Measurements were performed by two nutrition specialised nurses.

\section{Data Analysis}

Continuous variables were summarised by using the mean, standard deviation (SD), median and interquartile range. Categorical variables were summarised in frequencies and percentages. The data were stratified by sex and urban or rural areas. Chi-square was used to find possible associations between sociodemographic factors with participants' nutrition behavior. The comparison of the difference between the social demographic characteristics was conducted using odds ratio (OR) and 95\% Cls. Data analysis will be led by using IBM SPSS Statistics 27.

\section{Results}

The sociodemographic characteristics are shown in Table 1. A total of 235 participants (114 urban/ 121 rural) were interviewed. Overall, the mean age was 47.6 years $(M=47.6 ; S D=14.8) .89$ of the participants were male and 146 were female, with a significantly lower percentage of male in rural areas than in urban. $82.5 \%$ in urban and $62.8 \%$ in rural regions were married $(p=0.003)$. Most participants completed elementary school or less $(62.3 \%$ vs. $81.8 \%)$, followed by secondary school ( $28.9 \%$ vs. $12.4 \%)$ and postsecondary school ( $8.8 \%$ vs. $5.8 \%)$ with significant differences between urban and rural $(p=0.003)$. In urban regions, $32.5 \%$ were farmers, $13.2 \%$ were formally employed, $49.1 \%$ were self- 
employed. In the rural regions, $60.3 \%$ were farmers, $6.6 \%$ were formally employed, $28.9 \%$ were self-employed and $4.1 \%$ were other $(p<0.0001)$.

In urban regions a significantly smaller percentage of people have a monthly income less than $\$ 50(41.2 \%$ vs. $69.4 \%)$ whereas there is a higher percentage of people having an income between $\$ 50-100(30.7 \% \mathrm{vs} .17 .4 \%)$ and more than $\$ 100(28.1 \%$ vs. $13.2 \%)$ compared to the rural regions $(\mathrm{p}<0.0001)($ Table 1$)$. Women in rural areas have an income less than $\$ 50(75.3 \%)$ whereas men earn more than $\$ 100(31.3 \%)(p=0.002)$. In urban regions no significant differences were observed (Table 4).

\section{Anthropometric data, health data and physical activity}

Considering BMI, differences between the urban and rural regions could be observed (Table 2). There is a positive association between living in an urban region and the development of being overweight (OR 2.44; 95\% Cl: 1.32-4.51) $(p=0.0021)$. BMI shows no difference among the genders.

$51.7 \%$ participants from the urban and $71.1 \%$ from the rural areas are satisfied with their weight. The urban region is positively associated with being unsatisfied with weight (OR 2.29; 95\% Cl 1.29-4.07) $(p=0.0023)$ and also with the feeling of problems because of weight (OR 1.81; 95\% Cl 0.88-3.75) $(p=0.083)$.

\section{Nutritional Behaviour and Food Consumption and Lifestyle}

\section{Food-gathering}

The survey showed that residents from both areas frequently buy their food from the local market with $78.9 \%$ of urban and $66.1 \%$ of rural individuals doing so. Food from personal cultivation of the field to house is used by $46.5 \%$ in urban and $54.5 \%$ in rural areas. The minority from both regions are getting their edibles from the supermarket referred by $5.3 \%$ and $0.8 \%$ each.

\section{Nutritional practice}

The results are presented in figure 1. 35.1\% in urban and $43.0 \%$ in rural areas skip their breakfast,t and $11.4 \%$ compared to $19.8 \%$ skip evening meals more than once a week. For skipping lunch more than once a week, there are significant differences found between urban and rural areas ( $57.0 \%$ and $37.2 \% ; p=0.002) .35 .1 \%$ in urban and $23.1 \%$ in rural areas skip meals, snacking instead on most days $(p=0.044)$. The use of alcohol and cigarette smoking in urban vs. rural were $43 \%$ vs $33.1 \%$ and $1.8 \%$ vs. $1.7 \%$ respectively, without significant differences between the regions.

The correlations between nutrition behaviour and lifestyle and residence are shown in fig.1. No significant differences could be observed regarding sex.

\section{Food consumption}

Within the topical groups (Fruits and Vegetables, Fat, Starchy Food, Salt, Drinks and Alcohol) the answers to all questions show a positive correlation with urban region, which in most cases is significant. Considering the topic Sugar Consumption, a negative correlation with urban regions was observed. Detailed information is shown in table 6.

Regarding sex, the results within the topical groups Drinks and Salt reflect significant differences between male and female (table 6). 
The evaluation of the level of physical activity is shown in Table 6. There is a negative association shown between intensive physical activity at work for at least 10 minutes in individuals living in urban areas $(\mathrm{OR}=0.71 ; 95 \% \mathrm{Cl} 0.40$ 1.24) $(p=0.193)$, likewise for intensive sports, fitness and leisure activities for at least 10 minutes $(O R=0.78 ; 95 \% \mathrm{Cl}$ 0.41-1.48) ( $p=0.419)$. In both evaluations no significant difference between the sexes has been observed.

Participants from urban and from rural regions that answered affirmatively about doing work that involves vigorous intensity, are working a mean of 4.67 days [SD=1.835] and 4.66 days $[S D=1.811]$ a week $(p=0.975)$ with a mean time of activity of $5.51 \mathrm{~h}[S D=3,76]$ and $4.70 \mathrm{~h}[S D=3.01]$ a day respectively $(p=0.176)$.

Participants from urban and from rural regions that answered affirmatively about doing vigorous-intensity sports for at least 10 minutes, are active a mean of 3.6 days [SD =2.26] and 3.18 days $[S D=1.63](p=0.415)$ a week and a mean time of $2.59 \mathrm{~h}[S D=2.07]$ and $2.90 \mathrm{~h}[S D=2.13]$ a day respectively $(\mathrm{p}=0.570)$.

Considering the data about traveling to and from places by walking or bicycle for at least 10 minutes continuously, people from urban and rural areas declared 4.63 days $[S D=2.03]$ vs. 5.50 days $[S D=2.00]$ respectively $(p=0.006)$.

\section{Discussion}

The objective of this study was to gain a deeper understanding of the relationship between lifestyle factors and dietary behaviors among participants of cancer prevention events in Moshi Urban, Moshi Rural, and Meru District.

Our results highlight variations between male and female participants at the three PrevACamps and disparities between rural and urban residents in (1) BMI, (2) physical activity and (3) nutrition behaviors such as intake of fruits and vegetables, processed meats, sugar and salt, skipping meals and alcohol consumption.

\section{Variations between male and female participants}

Results from PrevACamps in rural areas show that women participated in cancer prevention more than men. This discrepancy implies that women are interested in cancer prevention when these programs are in nearby settings. A previous study from Tanzania postulated that rural women's health status was significantly worse than men. Low education, socioeconomic status, and lower quality health care for rural women were highlighted as barriers [18]. Another study reported that over $80 \%$ of women living in rural areas do not have access to health facilities [19]. However, the results of PrevACamp in Moshi Urban show that men and women were equally represented. One explanation for participation could be that educational, occupational and income levels are better for both sexes in urban areas than in rural areas. Better educational status could at least partially explain the comparatively high participation of men in urban areas, assuming that educational status correlates with better health awareness [25] [26] [27].

The results indicated no profound differences in eating behavior between men and women. Findings were that men would choose healthier convenience foods when available and drink more during their workday than women. In addition, men reported regularly choosing convenience foods and processed meats.

\section{Disparities between rural and urban participants}


First, our data indicate that participants from urban regions have a higher BMI. More than two-thirds of participants from urban regions are overweight or have obesity compared to rural regions with about $50 \%$. These findings are in line with previous observations of increased cases of obesity in urban regions of Tanzania [20] [28] [29]. Elevated BMI and less physical activity are associated with cardiovascular disease [30] [25], fatty liver disease [26], and some cancers [27] [31] [32]. There is also evidence of initial BMI and increased cancer mortality [33].

In tandem, our results show lower satisfaction with body weight and higher rates of health problems among participants from the urban region. In consideration that higher BMI are associated with the above-mentioned diseases, it might be possible that people from urban regions have a higher risk to develop health related problems, different metabolic diseases and cancer than people from rural regions. However, when interpreting these results, it is important to consider differences in body composition. Participants who have a high BMI in combination with a high percentage of lean body mass do not necessarily have to be considered overweight or obese. Differences in body composition are known from several ethnic groups and races [34]. So more profound investigations about the body composition of the participants may give a better understanding.

Second, our data confirm that living in urban areas is negatively associated with an active lifestyle. In 2019, McTiernan et al. summarised that physical activity leads to a reduction in the risk of developing carcinomas [27]. Amongst them are carcinoma of the bladder, breast, colon, endometrium and esophagus [27] [35]. In addition to physical inactivity, other risk factors include obesity, sex hormones, insulin resistance, insulin-related factors, adiponectin, systemic inflammation, low vitamin D, and immune disorders that can trigger cancers [35] [36] [37]. To what extent less physical activity in urban compared to rural regions leads to an elevation of cancer cases needs further evaluation.

Third, our results indicated a change towards a western lifestyle in the urban regions. This is observed by people replacing lunch with snacking, frequently using salt while cooking, increasing intake of processed meats, basing main meals around starchy foods, and drinking alcohol and sweetened sodas at elevated levels. This is in line with previous findings [20] [38]. Considering the behavior to snack frequently, snacks are high in energy but less rich in nutrients, leading to higher intakes of energy than needed [39]. Moreover, snacking does not guarantee to cover the daily need of nutrients. A good education about healthy nutrition may lead to healthy snacking pattern and seems to be a possible alternative if the main meal cannot be ensured. However, snacking while doing other activities might be associated with less satiety and higher food consumption [40].

The frequent use of salt reported by the participants is also observed in other countries from Sub-Saharan Africa [41]. However, a study about the salt consumption worldwide showed that the salt intake in Sub-Saharan Africa East was the lowest worldwide in 2013. The urbanization and change into a more western diet might lead to a rise of salt intake [42]. The high salt consumption levels in our findings reflect the extensive consumption of processed meat, also reported by the participants.

In addition, our results show that substantial amounts of sweetened and starchy foods and sweetened lemonade are crucial in urban and rural regions. A study showed that this high consumption, especially of sweetened sodas, is associated with many health-related problems [38].

The elevated intake of alcohol in Moshi Urban is consistent with previous findings by Temba et al. 2021 [20]. Also data from South Africa confirm this trend [43]. However, there appears to be wide variation between the regions in different countries [43] [37]. Religion, culture, and education seem to be important factors, which may influence alcohol intake.

Interestingly, our survey indicated that people from urban regions eat more fruits and vegetables, choose healthy food preparation alternatives instead of fried foods, and do not add sugar to meals too often. They also reported better 
drinking habits with plenty of fluids, including water, and fewer sweetened beverages compared to people from rural areas.

The elevated consumption of fruits was not expected but might be a result of the season in which the survey was implemented. An existing study showed that there might be seasonal changes in food patterns in Kilimanjaro-region, with a change towards a more healthy way of nutrition during dry season [20]. In addition, Temba et al. identified a number of food-derived metabolites which have an impact on immune response and inflammatory events [44]. Consequently, there is evidence that nutrition impacts immune status. The researchers reasoned that plant based traditional diets in Tanzania are beneficial for health. The frequent consumption of fruits and vegetables could also be due to a greater level of education in the urban area. Better education might be associated with an increased understanding for healthy nutrition and a healthier lifestyle.

Considering the rhythm of food intake, many participants skip breakfast and lunch. Dinner is not skipped that often. Having dinner more regularly than breakfast and lunch may be a traditional behavior maintaining the feeling of belonging within families, as it is common in African countries.

\section{Limitation}

Study findings cannot be generalized for the Tanzanian population as our sample represents voluntarily attending people from three region in Northern Tanzania.

However, this survey gives an overview about the differences in lifestyle between urban and rural areas of the Kilimanjaro region in Tanzania. These data are based on a questionnaire which was implemented retrospectively during a cancer screening event. To gain further information about nutritional changes, methods like $24 \mathrm{~h}$ protocols of food intake and activity protocols in a greater variety of residents are suitable.

\section{Conclusion}

In summary, this study shows that rural women in particular are more interested in cancer prevention than men. People in rural areas are more physically active and less overweight than those in urban areas. The cause is manifold, yet they hint at a lack of health care for women and a progressing urbanisation according to Western patterns.

In urban areas, an unhealthy diet of sweetened, starchy foods and beverages and a lack of physical activity have a positive effect on obesity, a risk factor for cancer.

Summarizing the negative correlation by low-intensity physical work and sports, people living in rural areas seem to have a more active lifestyle than those living in urban areas. Although people eat more healthy foods compared to rural populations, they tend to have high BMIs. Physical inactivity will be a more serious problem in Tanzania in the future, contributing further to the risk of cancer.

\section{Declarations}

\section{Statement conflict of Interest:}

The authors declare that they have no competing interests.

\section{Ethical approval and consent to participate:}


Each participant over 18 years completed a consent form prior to the interview.

Participants have filled out a consent form indicating that the data will be published

All data and materials are available.

\section{Ethical approval is available.}

Authors have no competing interests are present

\section{Funding:}

The organization of the cancer awareness campaigns were fund for by the Bavarian State Church.

\section{Contributions of the authors}

Antje Henke: writing part methods and discussion, data analysis, proof reading

Susann Rosenbaum: writing part results, data analysis, proof reading

Furaha Serventi: resources, data collection and analizes, proof reading

Oliver Henke: data analysis, proof reading

\section{Acknowledgements}

We thank the entire team at the Cancer Care Centre at KCMC for their support.

\section{References}

1. World Health Organization (WHO). Keyfacts cancer. [cited 2021 August 16]. Available from: https://www.who.int/cancer/resources/keyfacts/en/. 2019

2. Key TJ, Schatzkin A, Willett WC, Allen NE, Spencer EA, Travis RC. Diet, nutrition and the prevention of cancer. Public Health Nutr. 2004 Feb;7(1A):187-200. doi: 10.1079/phn2003588. PMID: 14972060.2004.

3. Kałędkiewicz E, Szostak-Węgierek D. Dietary practices and nutritional status in survivors of breast cancer. Rocz Panstw Zakl Hig. 2018;69(2):175-182. PMID: 29766696. 2018

4. Sung H, Siegel RL, Torre LA, Pearson-Stuttard J, Islami F, Fedewa SA, Goding Sauer A, Shuval K, Gapstur SM, Jacobs EJ, Giovannucci EL, Jemal A. Global patterns in excess body weight and the associated cancer burden. CA Cancer J Clin. 2019 Mar;69(2):88-112. doi: 10.3322/caac.21499. Epub 2018 Dec 12. PMID: 30548482. 2019.

5. Vorster HH, Kruger A, Margetts BM. The nutrition transition in Africa: can it be steered into a more positive direction? Nutrients. 2011 Apr;3(4):429-41. doi: 10.3390/nu3040429. Epub 2011 Apr 11. PMID: 22254104; PMCID: PMC3257689.

6. Unwin N, Setel P, Rashid S, Mugusi F, Mbanya JC, Kitange H, Hayes L, Edwards R, Aspray T, Alberti KG. Noncommunicable diseases in sub-Saharan Africa: where do they feature in the health research agenda? Bull World Health Organ. 2001;79(10):947-53. Epub 2001 Nov 1. PMID: 11693977; PMCID: PMC2566676. 2001.

7. Zubery D, Kimiywe J, Martin HD. Prevalence of Overweight and Obesity, and Its Associated Factors Among Healthcare Workers, Teachers, and Bankers in Arusha City, Tanzania. Diabetes Metab Syndr Obes. 2021 Feb 2;14:455465. doi: 10.2147/DMSO.S283595. PMID: 33564252; PMCID: PMC7866920. 2021 
8. Pallangyo, P., Mkojera, Z. S., Hemed, N. R., Swai, H. J., Misidai, N., Mgopa, L., Janabi, M., Obesity epidemic in urban Tanzania: a public health calamity in an already overwhelmed and fragmented health system. BMC Endocrine Disorders, 20(1). doi:10.1186/s12902-020-00631-3 2020.

9. Henke A, Kluge U, Borde T, Mchome B, Serventi F, Henke O. Tanzanian women's knowledge about Cervical Cancer and HPV and their prevalence of positive VIA cervical screening results. Data from a Prevention and Awareness Campaign in Northern Tanzania, 2017 - 2019. Glob Health Action. 2021 Jan 1;14(1):1852780. doi: 10.1080/16549716.2020.1852780. PMID: 33371824; PMCID: PMC7782163. 2021

10. Sunguya BF, Zhu S, Mpembeni R, Huang J. Trends in prevalence and determinants of stunting in Tanzania: an analysis of Tanzania demographic health surveys (1991-2016). Nutr J. 2019 Dec 10;18(1):85. doi: 10.1186/s12937-019-0505-8. PMID: 31823827; PMCID: PMC6904996. 2019

11. Temba GS, Kullaya V, Pecht T, Mmbaga BT, Aschenbrenner AC, Ulas T, Kibiki G, Lyamuya F, Boahen CK, Kumar V, Joosten LAB, Schultze JL, van der Ven AJ, Netea MG, de Mast Q. Urban living in healthy Tanzanians is associated with an inflammatory status driven by dietary and metabolic changes. Nat Immunol. 2021 Mar;22(3):287-300. doi: 10.1038/s41590-021-00867-8. Epub 2021 Feb 11. PMID: 33574617.2021

12. Singer R, Henke A, Alloyce JP, Serventi F, Massawe A, Henke O. Repetitive Cancer Training for Community Healthcare Workers: an Effective Method to Strengthen Knowledge and Impact on the Communities: Results from a Pilot Training at Kilimanjaro Region, Tanzania. J Cancer Educ. 2021 Jun;36(3):470-477. doi: 10.1007/s13187019-01648-6. PMID: 31707642. 2019.

13. National Buero of Statistic, Ministry of Finance. National Panel Survey Wave 3, 2012 - 2013: [cited 2021 August 16]. Available from:

https://www.nbs.go.tz/nbs/takwimu/Statistical_Methods_and_Standards/NPS_Wave_3\%20_Final\%20_Report.pdf. 2014.

14. World Data Atlas. World Data Atlas United Republic of Tanzania/ Kilimanjaro Region. 2012: [cited 2021 August 16]. Available from: https://knoema.com/atlas/United-Republic-of-Tanzania/Kilimanjaro-Region, 2012.

15. World Health Organization (WHO)., Body mass index - BMI. ([cited 2021 August 16] Available from: https://www.euro.who.int/en/health-topics/disease-prevention/nutrition/a-healthy-lifestyle/body-mass-index-bmi, 2021.

16. Kliemann N, Wardle J, Johnson F, Croker H. Reliability and validity of a revised version of the General Nutrition Knowledge Questionnaire. Eur J Clin Nutr. 2016 Oct;70(10):1174-1180. doi: 10.1038/ejcn.2016.87. Epub 2016 Jun 1. PMID: 27245211; PMCID: PMC5014128. 2016

17. Mwanyangala MA, Mayombana C, Urassa H, Charles J, Mahutanga C, Abdullah S, Nathan R. Health status and quality of life among older adults in rural Tanzania. Glob Health Action. 2010 Sep 27;3. doi: 10.3402/gha.v3i0.2142. PMID: 20975983; PMCID: PMC2958089. 2010.

18. Cooper EC, Maher JA, Naaseh A, Crawford EW, Chinn JO, Runge AS, Lucas AN, Zezoff DC, Bera KR, Dinicu Al, White KM, Tewari SE, Hari A, Bernstein M, Chang J, Ziogas A, Pearre DC, Tewari KS. Implementation of human papillomavirus video education for women participating in mass cervical cancer screening in Tanzania. Am J Obstet Gynecol. 2021 Jan;224(1):105.e1-105.e9. doi: 10.1016/j.ajog.2020.07.018. Epub 2020 Jul 17. PMID: 32682861.2021

19. Song X, Tabák AG, Zethelius B, Yudkin JS, Söderberg S, Laatikainen T, Stehouwer CD, Dankner R, Jousilahti P, Onat A, Nilsson PM, Satman I, Vaccaro O, Tuomilehto J, Qiao Q; DECODE Study Group. Obesity attenuates gender differences in cardiovascular mortality. Cardiovasc Diabetol. 2014 Oct 19;13:144. doi: 10.1186/s12933-014-01445. PMID: 25928355; PMCID: PMC4212094. 2014. 
20. Schiavo L, Busetto L, Cesaretti M, Zelber-Sagi S, Deutsch L, lannelli A. Nutritional issues in patients with obesity and cirrhosis. World J Gastroenterol. 2018 Aug 14;24(30):3330-3346. doi: 10.3748/wjg.v24.i30.3330. PMID: 30122874; PMCID: PMC6092576. 2018.

21. McTiernan A, Friedenreich CM, Katzmarzyk PT, Powell KE, Macko R, Buchner D, Pescatello LS, Bloodgood B, Tennant B, Vaux-Bjerke A, George SM, Troiano RP, Piercy KL; 2018 PHYSICAL ACTIVITY GUIDELINES ADVISORY COMMITTEE*. Physical Activity in Cancer Prevention and Survival: A Systematic Review. Med Sci Sports Exerc. 2019 Jun;51(6):1252-1261. doi: 10.1249/MSS.0000000000001937. PMID: 31095082; PMCID: PMC6527123. 2019.

22. Aspray TJ, Mugusi F, Rashid S, Whiting D, Edwards R, Alberti KG, Unwin NC; Essential Non-Communicable Disease Health Intervention Project. Rural and urban differences in diabetes prevalence in Tanzania: the role of obesity, physical inactivity and urban living. Trans R Soc Trop Med Hyg. 2000 Nov-Dec;94(6):637-44. doi: 10.1016/s00359203(00)90216-5. PMID: 11198647.2000

23. Pallangyo P, Mkojera ZS, Hemed NR, Swai HJ, Misidai N, Mgopa L, Bhalia S, Millinga J, Mushi TL, Kabeya L, Omar A, Kaijage A, Mulashani R, Mosha S, Mwapinga F, Janabi M. Obesity epidemic in urban Tanzania: a public health calamity in an already overwhelmed and fragmented health system. BMC Endocr Disord. 2020 Sep 29;20(1):147. doi: 10.1186/s12902-020-00631-3. PMID: 32993615; PMCID: PMC7526153.2020.

24. Khan SS, Ning H, Wilkins JT, Allen N, Carnethon M, Berry JD, Sweis RN, Lloyd-Jones DM. Association of Body Mass Index With Lifetime Risk of Cardiovascular Disease and Compression of Morbidity. JAMA Cardiol. 2018 Apr 1;3(4):280-287. doi: 10.1001/jamacardio.2018.0022. PMID: 29490333; PMCID: PMC5875319.

25. Kelly ME, Duff H, Kelly S, McHugh Power JE, Brennan S, Lawlor BA, Loughrey DG. The impact of social activities, social networks, social support and social relationships on the cognitive functioning of healthy older adults: a systematic review. Syst Rev. 2017 Dec 19;6(1):259. doi: 10.1186/s13643-017-0632-2. PMID: 29258596; PMCID: PMC5735742. 2017.

26. Arem H, Park Y, Pelser C, Ballard-Barbash R, Irwin ML, Hollenbeck A, Gierach GL, Brinton LA, Pfeiffer RM, Matthews CE. Prediagnosis body mass index, physical activity, and mortality in endometrial cancer patients. J Natl Cancer Inst. 2013 Mar 6;105(5):342-9. doi: 10.1093/jnci/djs530. Epub 2013 Jan 7. PMID: 23297041; PMCID: PMC3589256. 2013.

27. Taghizadeh M, Memarzadeh MR, Asemi Z, Esmaillzadeh A. Effect of the cumin cyminum L. Intake on Weight Loss, Metabolic Profiles and Biomarkers of Oxidative Stress in Overweight Subjects: A Randomized Double-Blind Placebo-Controlled Clinical Trial. Ann Nutr Metab. 2015;66(2-3):117-24. doi: 10.1159/000373896. Epub 2015 Mar 3. PMID: 25766448. 2015.

28. Heymsfield SB, Peterson CM, Thomas DM, Heo M, Schuna JM Jr. Why are there race/ethnic differences in adult body mass index-adiposity relationships? A quantitative critical review. Obes Rev. 2016 Mar;17(3):262-75. doi: 10.1111/obr.12358. Epub 2015 Dec 11. PMID: 26663309; PMCID: PMC4968570. 2016.

29. Wolin KY, Yan Y, Colditz GA, Lee IM. Physical activity and colon cancer prevention: a meta-analysis. Br J Cancer. 2009 Feb 24;100(4):611-6. doi: 10.1038/sj.bjc.6604917. Epub 2009 Feb 10. PMID: 19209175; PMCID: PMC2653744.2009.

30. Friedenreich CM, Neilson HK, Lynch BM. State of the epidemiological evidence on physical activity and cancer prevention. Eur J Cancer. 2010 Sep;46(14):2593-604. doi: 10.1016/j.ejca.2010.07.028. PMID: 20843488. 2010

31. Kruk, J., Lifestyle Components and Primary Breast Cancer Prevention. Asian Pacific Journal of Cancer Prevention, Vol 15, 10543-10555., 2014.

32. Nicklas TA, O'Neil CE, Fulgoni VL 3rd. Snacking patterns, diet quality, and cardiovascular risk factors in adults. BMC Public Health. 2014 Apr 23;14:388. doi: 10.1186/1471-2458-14-388. PMID: 24754905; PMCID: PMC4108013. 
2014

33. Nicklas TA, O'Neil CE, Fulgoni VL 3rd. Snacking patterns, diet quality, and cardiovascular risk factors in adults. BMC Public Health. 2014 Apr 23;14:388. doi: 10.1186/1471-2458-14-388. PMID: 24754905; PMCID: PMC4108013. 2014.

34. Jessen N, Santos A, Damasceno A, Silva-Matos C, Severo M, Padrão P, Lunet N. Knowledge and behaviors regarding salt intake in Mozambique. Eur J Clin Nutr. 2018 Dec;72(12):1690-1699. doi: 10.1038/s41430-018-0125y. Epub 2018 Mar 27. PMID: 29588530. 2018

35. Powles J, Fahimi S, Micha R, Khatibzadeh S, Shi P, Ezzati M, Engell RE, Lim SS, Danaei G, Mozaffarian D; Global Burden of Diseases Nutrition and Chronic Diseases Expert Group (NutriCoDE). Global, regional and national sodium intakes in 1990 and 2010: a systematic analysis of $24 \mathrm{~h}$ urinary sodium excretion and dietary surveys worldwide. BMJ Open. 2013 Dec 23;3(12):e003733. doi: 10.1136/bmjopen-2013-003733. PMID: 24366578; PMCID: PMC3884590. 2013

36. Oyebode, O., Pape, U.J., Laverty, A.A., Lee, J.T., Bhan, N., Millett, C., Rural, Urban and Migrant Differences in NonCommunicable Disease Risk-Factors in Middle Income Countries: A Cross-Sectional Study of WHO-SAGE Data. PLoS ONE 10(4): e0122747. doi:10.1371/journal.pone.012274, 2015.

37. Im PK, Millwood IY, Guo Y, Du H, Chen Y, Bian Z, Tan Y, Guo Z, Wu S, Hua Y, Li L, Yang L, Chen Z; China Kadoorie Biobank (CKB) collaborative group. Patterns and trends of alcohol consumption in rural and urban areas of China: findings from the China Kadoorie Biobank. BMC Public Health. 2019 Feb 20;19(1):217. doi: 10.1186/s12889-0196502-1. PMID: 30786877; PMCID: PMC6383236. 2019

38. Khan, T.A., Sievenpiper J.L., Controversies about sugars: results from systematic reviews and meta-analyses on obesity, cardiometabolic disease and diabetes. Eur J Nutr. 2016; 55(Suppl 2): 25-43., 2016.

\section{Tables}

Table 1: Socio-demographic information ( $\mathrm{N}=235)$ 


\begin{tabular}{|c|c|c|c|c|}
\hline Variables & $\begin{array}{l}\text { Total } \\
\mathrm{N}=235\end{array}$ & $\begin{array}{l}\text { Urban } \\
\mathbf{N}=114\end{array}$ & $\begin{array}{l}\text { Rural } \\
\mathbf{N}=121\end{array}$ & P-values \\
\hline Age (years) & & & & 0.477 \\
\hline [Mean; SD] & {$[47.6 ; 14.8]$} & {$[48.4 ; 15.7]$} & {$[46.9 ; 13.9]$} & \\
\hline $20-29$ & 28 & $15(13.2)$ & $13(10.7)$ & \\
\hline $30-39$ & 42 & 19(16.7) & $23(19.0)$ & \\
\hline $40-49$ & 67 & $28(24.6)$ & $39(32.2)$ & \\
\hline $50+$ & 98 & $52(45.6)$ & $46(38.0)$ & \\
\hline $\operatorname{Sex}(\%)$ & & & & $<0.0001$ \\
\hline Male & 89 & $57(50.0)$ & $32(26.4)$ & \\
\hline Female & 146 & $57(50.0)$ & $89(73.6)$ & \\
\hline Religion (\%) & & & & 0.003 \\
\hline Christian & 215 & $98(86.0)$ & $117(96.7)$ & \\
\hline Muslim & 20 & $16(14.0)$ & $4(3.3)$ & \\
\hline Marital status (\%) & & & & 0.003 \\
\hline Married & 170 & $94(82.5)$ & $76(62.8)$ & \\
\hline Single & 42 & $12(10.5)$ & $30(24.8)$ & \\
\hline Divorced/widowed & 23 & $8(7.0)$ & $15(12.4)$ & \\
\hline Education level (\%) & & & & 0.003 \\
\hline Primary/below & 170 & $71(62.3)$ & $99(81.8)$ & \\
\hline Secondary & 48 & $33(28.9)$ & $15(12.4)$ & \\
\hline Above secondary & 17 & $10(8.8)$ & $7(5.8)$ & \\
\hline Occupation (\%) & & & & $<0.0001$ \\
\hline Farmer & 110 & $37(32.5)$ & $73(60.3)$ & \\
\hline Formal employed & 23 & $15(13.2)$ & $8(6.6)$ & \\
\hline Self-employed & 91 & $56(49.1)$ & $35(28.9)$ & \\
\hline Other* & 11 & $6(5.3)$ & $5(4.1)$ & \\
\hline Income (\%) & & & & $<0.0001$ \\
\hline$<50$ & 131 & $47(41.2)$ & $84(69.4)$ & \\
\hline $50-100$ & 56 & $35(30.7)$ & $21(17.4)$ & \\
\hline$>100$ & 48 & $32(28.1)$ & $16(13.2)$ & \\
\hline History of cancer ir & & & & \\
\hline
\end{tabular}




\begin{tabular}{|lllll|}
\hline Yes & 62 & $40(35.1)$ & $22(18.2)$ & 0.003 \\
\hline No & 173 & $74(64.9)$ & $99(81.8)$ & \\
\hline Have you ever had cancer? & & & & \\
\hline Yes & 2 & $1(0.9)$ & $1(0.8)$ & 0.966 \\
\hline No & 233 & $113(99.1)$ & $120(99.2)$ & \\
\hline
\end{tabular}

Body Mass Index (BMI) \& Nutrition Assessment: Result Summary

Table 2: The relationship between $\mathrm{BMI}$ and region( $\mathrm{N}=235)$

\begin{tabular}{|c|c|c|c|c|c|}
\hline \multirow[t]{3}{*}{ Variables } & \multicolumn{5}{|l|}{ Residence } \\
\hline & Urban & Rural & P-value & OR & $95 \% \mathrm{Cl}$ \\
\hline & $(\%)$ & (\%) & & & \\
\hline BMI $\left(\mathrm{kg} / \mathrm{m}^{2}\right)$ & & & 0.016 & & \\
\hline Underweight & $6(5.3)$ & 4(3.3) & & & \\
\hline Normal weight & $26(22.8)$ & $51(42.1)$ & & & \\
\hline Overweight & $42(36.8)$ & $37(30.6)$ & & & \\
\hline Obesity & 40(35.1) & $29(24.0)$ & & & \\
\hline Overweight all (Overweight + Obesity) & $82(71,9)$ & $66(54.6)$ & 0.0021 & 2.44 & {$[1.32 ; 4.51]$} \\
\hline Are you satisfied with your weight? & & & 0.005 & & \\
\hline Not at all & $19(16.7)$ & $6(5.0)$ & & & \\
\hline Less satisfied & $36(31.6)$ & $29(24.0)$ & & & \\
\hline Satisfied & $42(36.8)$ & $65(53.7)$ & & & \\
\hline Very Satisfied & $17(14.9)$ & $21(17.4)$ & & & \\
\hline Satisfied & $59(51.7)$ & $86(71.1)$ & 0.0023 & 2.29 & {$[1.29 ; 4.07]$} \\
\hline Not satisfied & $55(48.3)$ & $35(29.0)$ & & & \\
\hline Do you feel any problem because of your weight? & & & 0.083 & & \\
\hline Yes & $26(22.8)$ & $17(14.0)$ & & 1.81 & {$[0.88 ; 3.75]$} \\
\hline No & $88(77.2)$ & 104(86.0) & & & \\
\hline
\end{tabular}

Body Mass Index (BMI) \& Nutrition Assessment: Result Summary 
Table 3: The association between residence, sex by socio-demographic and information on cancer

\begin{tabular}{|c|c|c|c|c|c|c|}
\hline Variables & Urban & & & Rural & & \\
\hline & Male & Female & P-value & Male & Female & P-value \\
\hline Education & & & 0.174 & & & 0.040 \\
\hline Primary/below & $40(70.2)$ & $31(54.4)$ & & $27(84.4)$ & $72(80.9)$ & \\
\hline Secondary & $14(24.6)$ & 19 (33.3) & & $1(3.1)$ & $14(15.7)$ & \\
\hline Above secondary & $3(5.3)$ & $7(12.3)$ & & $4(12.5)$ & $3(3.4)$ & \\
\hline Occupation* & & & 0.379 & & & 0.055 \\
\hline Farmer & $21(36.8)$ & $16(28.1)$ & & $17(53.1)$ & $56(62.9)$ & \\
\hline Formal employed & $5(8.8)$ & $10(17.5)$ & & $5(15.6)$ & $3(3.4)$ & \\
\hline Self-employed & $27(47.4)$ & $29(50.9)$ & & $10(31.3)$ & $25(28.1)$ & \\
\hline Other & $4(7.0)$ & $2(3.5)$ & & 0 & $5(5.6)$ & \\
\hline Income & & & 0.065 & & & 0.002 \\
\hline$<50$ & $24(42.1)$ & $23(40.4)$ & & $17(53.1)$ & $67(75.3)$ & \\
\hline $50-100$ & $22(38.6)$ & $13(22.8)$ & & $5(15.6)$ & $16(18.0)$ & \\
\hline$>100$ & $11(19.3)$ & $21(36.8)$ & & $10(31.3)$ & $6(6.7)$ & \\
\hline History of cancer in your family & & & 0.432 & & & 0.132 \\
\hline Yes & $18((31.6)$ & $22(38.6)$ & & $3(9.4)$ & $19(21.3)$ & \\
\hline No & $39(68.4)$ & $35(61.4)$ & & $29(90.6)$ & $70(78.7)$ & \\
\hline
\end{tabular}

a. 3 cells (37.5\%) have expected count less than 5 . The minimum expected count is 1.32 .

Table 4: Nutrition and Residence $(\mathrm{N}=235)$ 
Residence

\begin{tabular}{|c|c|c|}
\hline Urban & Rura & $\begin{array}{l}\mathrm{P} \text { - } \\
\text { value }\end{array}$ \\
\hline
\end{tabular}

\section{FRUITS AND VEGETABLES}

Do you eat different types of fruit (e.g. avocado, orange, mango, water melon) and/or vegetables (e.g mchicha, sukuma wiki, chinese,

tembele, leshu) every day?

\begin{tabular}{|c|c|c|c|c|c|}
\hline Yes & $\begin{array}{l}85 \\
(74.6)\end{array}$ & $\begin{array}{l}61 \\
(50.4)\end{array}$ & 0.000 & 2.88 & $\begin{array}{l}{[1.60-} \\
5.21]\end{array}$ \\
\hline No & $\begin{array}{l}29 \\
(25.4)\end{array}$ & $\begin{array}{l}60 \\
(49.6)\end{array}$ & & & \\
\hline
\end{tabular}

Do you eat more than 4 different varieties of fruit each week? (e.g.

avocado, orange, mango, water melon)

\begin{tabular}{|c|c|c|c|c|c|}
\hline \multirow[t]{2}{*}{ Yes } & 71 & 28 & \multirow[t]{2}{*}{0.000} & \multirow[t]{2}{*}{5.48} & \multirow{2}{*}{$\begin{array}{l}{[3.00-} \\
10.10]\end{array}$} \\
\hline & $(62.3)$ & $(23.1)$ & & & \\
\hline \multirow[t]{2}{*}{ No } & 43 & 93 & & & \\
\hline & (37.7) & (76.9) & & & \\
\hline
\end{tabular}

Do you eat more than 4 different varieties of vegetables each week?

(e.g. avocado, orange, mango, water melon)

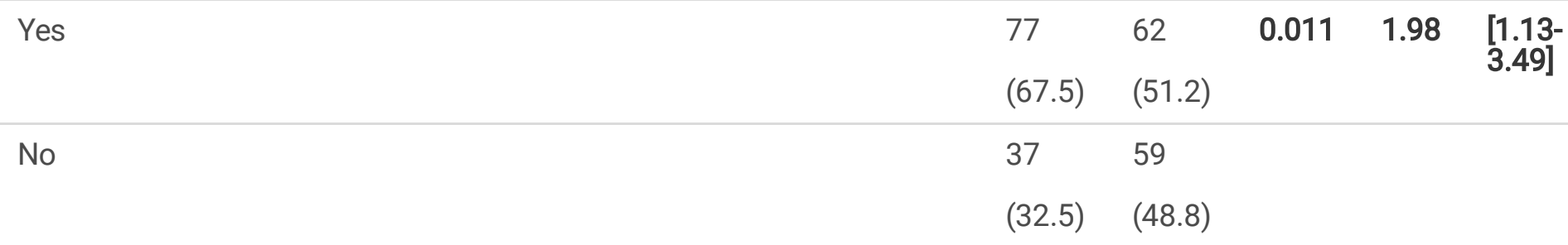

\section{FAT}

Do you choose baked, steamed or grilled food options when available, rather than fried foods (such as crisps and snacks, or fish and chips)?

\begin{tabular}{|c|c|c|c|c|c|}
\hline Yes & $\begin{array}{l}47 \\
(41.2)\end{array}$ & $\begin{array}{l}23 \\
(19.0)\end{array}$ & 0.000 & 2.99 & $\begin{array}{l}{[1.60-} \\
5.62]\end{array}$ \\
\hline \multirow[t]{2}{*}{ No } & 67 & 98 & & & \\
\hline & $(58.8)$ & $(81.0)$ & & & \\
\hline \multicolumn{6}{|c|}{ Do you include some unsalted nuts and seeds in your diet? } \\
\hline \multirow[t]{2}{*}{ Yes } & 42 & 10 & \multirow[t]{2}{*}{0.000} & \multirow[t]{2}{*}{6.48} & \multirow{2}{*}{$\begin{array}{l}{[2.91-} \\
14.76]\end{array}$} \\
\hline & $(36.8)$ & $(8.3)$ & & & \\
\hline \multirow[t]{2}{*}{ No } & 72 & 111 & & & \\
\hline & $(63.2)$ & $(91.7)$ & & & \\
\hline
\end{tabular}


Do you base your main meals around starchy foods? e.g, potatoes, ugali, cooked babana, rice or bread.

\begin{tabular}{|c|c|c|c|c|c|}
\hline \multirow[t]{2}{*}{ Yes } & & & & \multirow[t]{2}{*}{1.60} & \multirow[t]{2}{*}{$\begin{array}{l}{[0.32-} \\
8.64]\end{array}$} \\
\hline & (97.4) & (95.9) & $\begin{array}{l}\text { Yates } \\
0.784\end{array}$ & & \\
\hline \multirow[t]{2}{*}{ No } & 3 & 5 & & & \\
\hline & $(2.6)$ & $(4.1)$ & & & \\
\hline \multicolumn{6}{|c|}{$\begin{array}{l}\text { Do you regularly choose ugali or cooked banana or potatoes for your } \\
\text { meal a whole day? }\end{array}$} \\
\hline \multirow[t]{2}{*}{ Yes } & 107 & 102 & \multirow[t]{2}{*}{0.020} & \multirow[t]{2}{*}{2.85} & \multirow{2}{*}{$\begin{array}{l}{[1.07-} \\
7.82]\end{array}$} \\
\hline & (93.9) & (84.3) & & & \\
\hline \multirow[t]{2}{*}{ No } & 7 & 19 & & & \\
\hline & $(6.1)$ & (15.7) & & & \\
\hline
\end{tabular}

\section{SUGAR}

Do you regularly eat sugar-coated breakfast cereals or add sugar to your breakfast cereals?

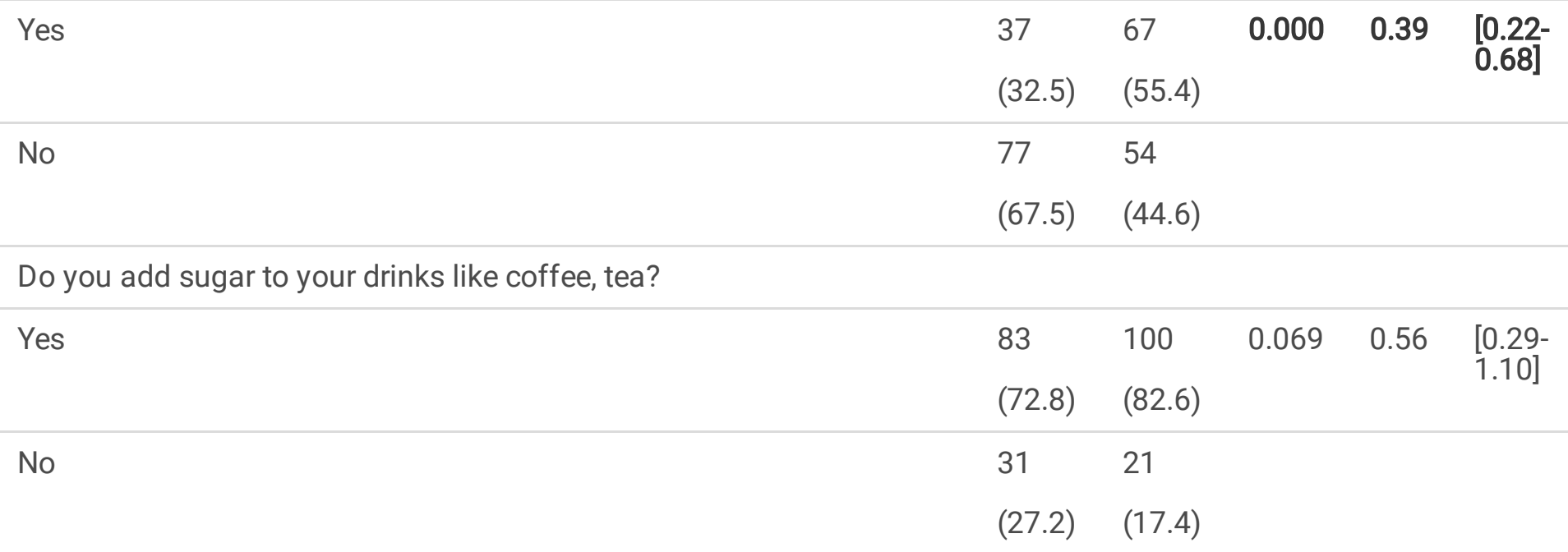

Do you like to drink soda?

With sugar

\begin{tabular}{|c|c|c|c|c|c|}
\hline Yes & $\begin{array}{l}52 \\
(45.6)\end{array}$ & $\begin{array}{l}35 \\
(28.9)\end{array}$ & 0.008 & 2.06 & $\begin{array}{l}{[1.16-} \\
3.66]\end{array}$ \\
\hline No & $\begin{array}{l}62 \\
(54.4)\end{array}$ & $\begin{array}{l}86 \\
(71.1)\end{array}$ & & & \\
\hline
\end{tabular}

SALT

Do you regularly add salt to food during cooking?

\begin{tabular}{|c|c|c|c|c|c|}
\hline Yes & $\begin{array}{l}86 \\
(75.4)\end{array}$ & $\begin{array}{l}76 \\
(62.8)\end{array}$ & 0.037 & 1.82 & $\begin{array}{l}{[1.00-} \\
3.33]\end{array}$ \\
\hline No & 28 & 45 & & & \\
\hline
\end{tabular}


Do you regularly add salt to meals at the table?

$\begin{array}{llllll}\text { Yes } & 27 & 28 & 0.922 & 1.03 & \text { [0.54- } \\ & (23.7) & (23.1) & & & 1.97] \\ \text { No } & 87 & 93 & & & \\ & (76.3) & (76.9) & & \end{array}$

Do you regularly eat savoury snacks at work?

For example, crisps or salted nuts

$\begin{array}{lllllll}\text { Yes } & 30 & 26 & 0.385 & 1.31 & {[0.69-} \\ & (26.3) & (21.5) & & & 2.49] \\ \text { No } & 84 & 95 & & & \\ & (73.7) & (78.5) & & \end{array}$

Do you regularly eat pre-prepared meals? For example,e.g

Fried pags of food

$\begin{array}{llllll}\text { Yes } & 36 & 24 & \mathbf{0 . 0 3 9} & \mathbf{1 . 8 7} & \begin{array}{l}\text { [0.99- } \\ \text { 3.54] }\end{array} \\ \text { No } & (31.6) & (19.8) & & & \\ & 78 & 97 & & & \\ \text { Do you regularly eat processed meats or smoked fish? } & (68.4) & (80.2) & & & \\ \text { Yes } & & & & & \\ & 43 & 18 & \mathbf{0 . 0 0 0} & \mathbf{3 . 4 7} & {\left[\begin{array}{l}\text { [1.77- } \\ \text { No }\end{array}\right.} \\ \text { No.83] } & (37.7) & (14.9) & & & \\ & 71 & 103 & & & \\ & (62.3) & (85.1) & & & \end{array}$

\section{DRINKS}

Do you drink plenty of fluids at regular intervals during the working day?

\begin{tabular}{|c|c|c|c|c|c|}
\hline Yes & $\begin{array}{l}74 \\
(64.9)\end{array}$ & $\begin{array}{l}43 \\
(35.5)\end{array}$ & 0.000 & 3.36 & $\begin{array}{l}{[1.90-} \\
5.95]\end{array}$ \\
\hline \multirow[t]{2}{*}{ No } & 40 & 78 & & & \\
\hline & (35.1) & $(64.5)$ & & & \\
\hline \multicolumn{6}{|c|}{ Do you opt for a variety of different drinks, including water, at work? } \\
\hline \multirow[t]{2}{*}{ Yes } & 72 & 42 & \multirow[t]{2}{*}{0.000} & \multirow[t]{2}{*}{3.22} & \multirow{2}{*}{$\begin{array}{l}{[1.83} \\
5.71]\end{array}$} \\
\hline & (63.2) & (34.7) & & & \\
\hline No & 42 & 79 & & & \\
\hline
\end{tabular}


Do you avoid sugary fizzy drinks?

\begin{tabular}{|c|c|c|c|c|c|}
\hline Yes & $\begin{array}{l}31 \\
(27.2)\end{array}$ & $\begin{array}{l}17 \\
(14.0)\end{array}$ & 0.013 & 2.29 & $\begin{array}{l}{[1.13} \\
4.65]\end{array}$ \\
\hline \multirow[t]{2}{*}{ No } & 83 & 104 & & & \\
\hline & (72.8) & (86.0) & & & \\
\hline
\end{tabular}

\section{ALCOHOL}

Do you drink less than 2-3 units of alcohol a day if you're a woman, or less than 3-4 units of alcohol a day if you're a man?

\begin{tabular}{|c|c|c|c|c|c|}
\hline Yes & $\begin{array}{l}42 \\
(36.8)\end{array}$ & $\begin{array}{l}58 \\
(47.9)\end{array}$ & 0.019 & 1.86 & $\begin{array}{l}{[1.07-} \\
3.25]\end{array}$ \\
\hline \multirow[t]{2}{*}{ No } & 72 & 63 & & & \\
\hline & (63.2) & (52.) & & & \\
\hline
\end{tabular}

Table 5: Nutrition and $\operatorname{Sex}(\mathrm{N}=235)$ 
Residence

$\begin{array}{lllll}\text { Male Female } & \begin{array}{l}\text { P- } \\ \text { value }\end{array} & \text { OR } & \begin{array}{l}95 \% \\ \mathrm{Cl}\end{array}\end{array}$

\section{FRUITS AND VEGETABLES}

Do you eat different types of fruit (e.g. avocado, orange, mango,

water melon) and/or vegetables (e.g mchicha, sukuma wiki,

chinese, tembele, leshu) every day?

\begin{tabular}{|c|c|c|c|c|c|}
\hline \multirow[t]{2}{*}{ Yes } & 56 & 90 & \multirow[t]{2}{*}{0.844} & 1.06 & \multirow{2}{*}{$\begin{array}{l}{[0.59-} \\
1.89]\end{array}$} \\
\hline & (62.9) & (61.6) & & & \\
\hline \multirow[t]{2}{*}{ No } & 33 & 56 & & & \\
\hline & (37.1) & (38.4) & & & \\
\hline
\end{tabular}

Do you eat more than 4 different varieties of fruit each week? (e.g.

avocado, orange, mango, water melon)

\begin{tabular}{|c|c|c|c|c|c|}
\hline \multirow[t]{2}{*}{ Yes } & 42 & 57 & \multirow[t]{2}{*}{0.220} & \multirow[t]{2}{*}{1.40} & \multirow{2}{*}{$\begin{array}{l}{[0.79-} \\
2.46]\end{array}$} \\
\hline & $(47.2)$ & $(39.0)$ & & & \\
\hline \multirow[t]{2}{*}{ No } & 47 & 89 & & & \\
\hline & $(52.8)$ & $(61.0)$ & & & \\
\hline
\end{tabular}

Do you eat more than 4 different varieties of vegetables each week?

(e.g. avocado, orange, mango, water melon)

\begin{tabular}{|c|c|c|c|c|c|}
\hline Yes & $\begin{array}{l}51 \\
(57.3)\end{array}$ & $\begin{array}{l}88 \\
(60.3)\end{array}$ & 0.653 & 0.89 & $\begin{array}{l}{[0.50-} \\
1.57]\end{array}$ \\
\hline No & $\begin{array}{l}38 \\
(42.7)\end{array}$ & $\begin{array}{l}58 \\
(39.7)\end{array}$ & & & \\
\hline
\end{tabular}

FAT

Do you choose baked, steamed or grilled food options when available, rather than fried foods (such as crisps and snacks, or fish and chips)?

\begin{tabular}{|c|c|c|c|c|c|}
\hline Yes & $\begin{array}{l}38 \\
(42.7)\end{array}$ & $\begin{array}{l}32 \\
(21.9)\end{array}$ & 0.001 & 2.65 & $\begin{array}{l}{[1.44-} \\
4.91]\end{array}$ \\
\hline \multirow[t]{2}{*}{ No } & 51 & 114 & & & \\
\hline & $(57.3)$ & $(78.1)$ & & & \\
\hline \multicolumn{6}{|c|}{ Do you include some unsalted nuts and seeds in your diet? } \\
\hline \multirow[t]{2}{*}{ Yes } & 24 & 28 & 0.163 & 1.56 & {$[0.80-$} \\
\hline & $(27)$ & $(19.2)$ & & & \\
\hline \multirow[t]{2}{*}{ No } & 65 & 118 & & & \\
\hline & $(73)$ & $(80.8)$ & & & \\
\hline
\end{tabular}


Do you regularly choose ugali or cooked banana or potatoes for your meal a whole day?

\begin{tabular}{|c|c|c|c|c|c|}
\hline Yes & $\begin{array}{l}82 \\
(92.1)\end{array}$ & $\begin{array}{l}127 \\
(87.0)\end{array}$ & 0.222 & 1.75 & $\begin{array}{l}{[0.66-} \\
4.83]\end{array}$ \\
\hline \multirow[t]{2}{*}{ No } & 7 & 19 & & & \\
\hline & $(7.9)$ & (13.0) & & & \\
\hline
\end{tabular}

\section{SUGAR}

Do you regularly eat sugar-coated breakfast cereals or add sugar to your breakfast cereals?

\begin{tabular}{|c|c|c|c|c|c|}
\hline Yes & $\begin{array}{l}41 \\
(46.1)\end{array}$ & $\begin{array}{l}63 \\
(43.2)\end{array}$ & 0.662 & 1.13 & $\begin{array}{l}{[0.64-} \\
1.98]\end{array}$ \\
\hline \multirow[t]{2}{*}{ No } & 48 & 83 & & & \\
\hline & $(53.9)$ & $(56.8)$ & & & \\
\hline \multicolumn{6}{|c|}{ Do you like to drink soda? } \\
\hline \multicolumn{6}{|c|}{ With sugar } \\
\hline \multirow[t]{2}{*}{ Yes } & 33 & 54 & \multirow[t]{2}{*}{0.989} & \multirow[t]{2}{*}{1.00} & \multirow{2}{*}{$\begin{array}{l}{[0.56-} \\
1.80]\end{array}$} \\
\hline & $(37.1)$ & $(37.0)$ & & & \\
\hline \multirow[t]{2}{*}{ No } & 56 & 92 & & & \\
\hline & $(62.9)$ & $(63.0)$ & & & \\
\hline
\end{tabular}

\section{SALT}

Do you regularly add salt to food during cooking?

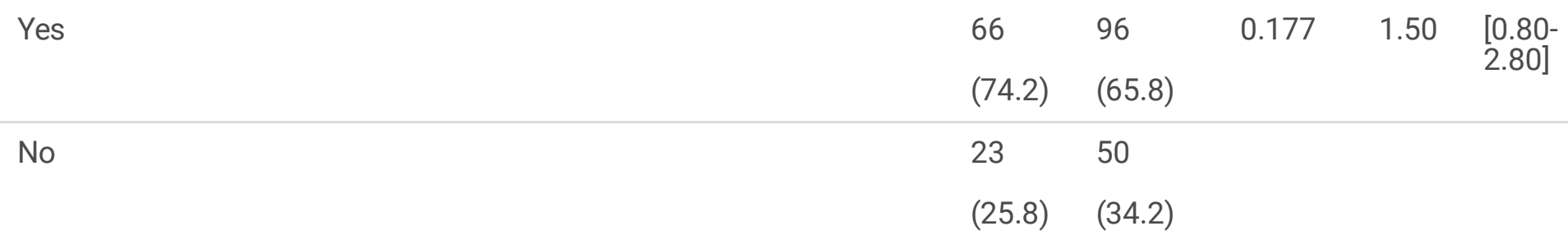

Do you regularly eat pre-prepared meals? For example,e.g

Fried pags of food

Yes

\begin{tabular}{lllll}
30 & 30 & 0.0248 & 1.97 & {$[1.04-$} \\
$(33.7)$ & $(20.5)$ & & & $3.72]$ \\
\hline 59 & 116 & & & \\
$(66.3)$ & $(79.5)$ & & & \\
\hline
\end{tabular}

Do you regularly eat processed meats or smoked fish?

Yes

$\begin{array}{lllll}30 & 31 & 0.034 & 1.89 & {[1.00-} \\ (33.7) & (21.2) & & & 3.56]\end{array}$




\section{DRINKS}

Do you drink plenty of fluids at regular intervals during the working day?

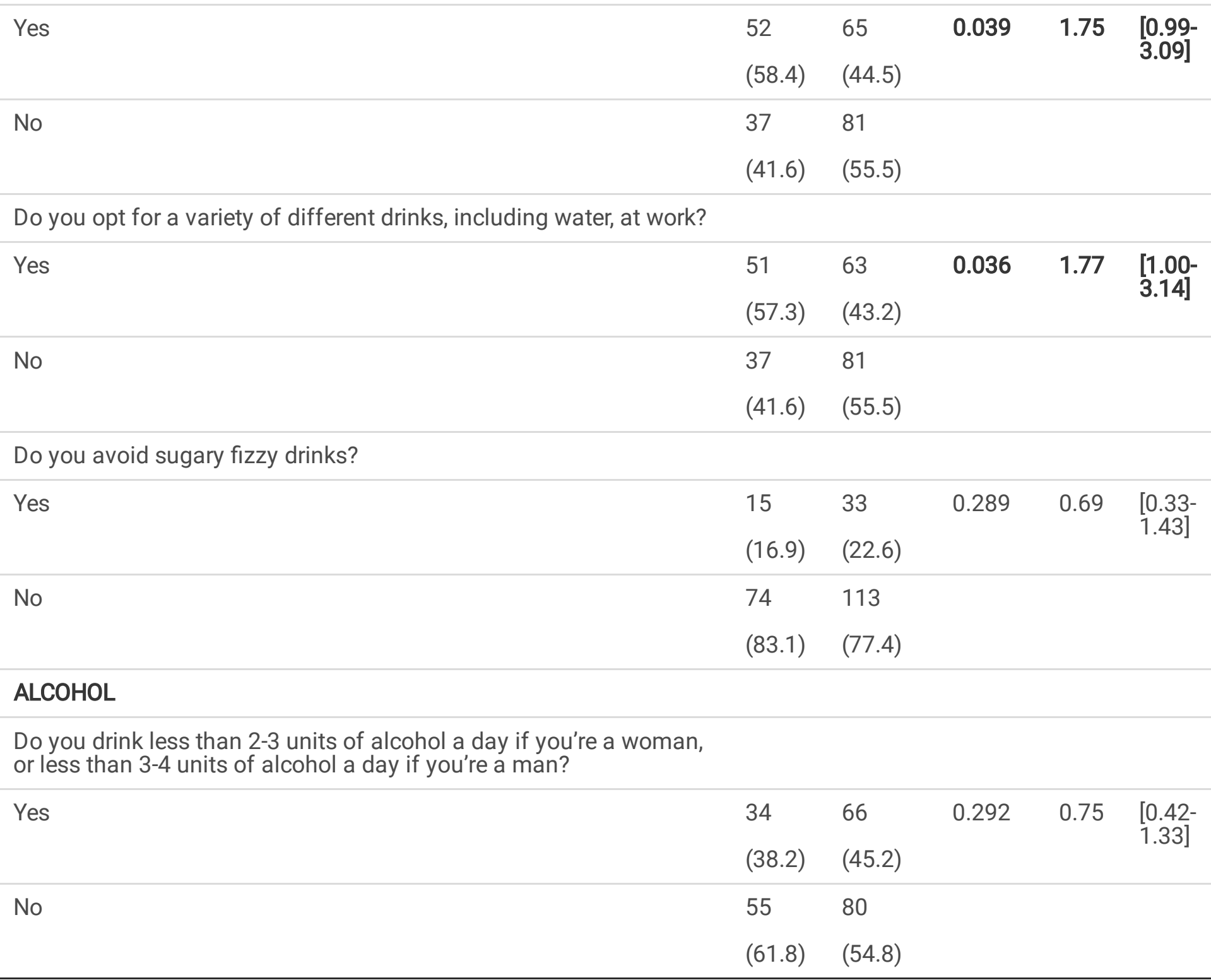

Table 6: The relationship between physical activity and residence $(N=235)$ 


\begin{tabular}{|c|c|c|c|c|c|c|c|}
\hline \multicolumn{8}{|l|}{ Variables } \\
\hline & & Total & Urban & Rural & $\begin{array}{l}\text { P- } \\
\text { value }\end{array}$ & OR & $\begin{array}{l}\mathrm{Cl} \\
95 \%\end{array}$ \\
\hline \multicolumn{8}{|l|}{ WORK } \\
\hline \multirow{2}{*}{$\begin{array}{l}\text { Does your work involve vigorous-intensity } \\
\text { activity that causes large increase in breathing, } \\
\text { or heart rate like carrying or lifting heavy loads, } \\
\text { digging or construction work for at least } 10 \\
\text { minutes continuously? (\%) }\end{array}$} & Yes & $\begin{array}{l}144 \\
(61.3)\end{array}$ & $65(57.0)$ & $\begin{array}{l}79 \\
(65.3)\end{array}$ & \multirow[t]{2}{*}{0.193} & 0.71 & $\begin{array}{l}{[0.40 ;} \\
1.24]\end{array}$ \\
\hline & No & $\begin{array}{l}91 \\
(38.7)\end{array}$ & $49(43.0)$ & $\begin{array}{l}42 \\
(34.7)\end{array}$ & & & \\
\hline \multirow{2}{*}{$\begin{array}{l}\text { In a typical week, on how many days do you do } \\
\text { vigorous- intensity activities as part of your } \\
\text { work? [Mean; SD] }\end{array}$} & $\mathrm{N}$ & 141 & 64 & 77 & \multirow[t]{2}{*}{0.975} & & \\
\hline & $\begin{array}{l}\text { [Mean; } \\
\text { SD] }\end{array}$ & $\begin{array}{l}4.67 \\
1.82\end{array}$ & $\begin{array}{l}4.67 \\
1.84\end{array}$ & $\begin{array}{l}4.66 \\
1.81\end{array}$ & & & \\
\hline \multirow{2}{*}{$\begin{array}{l}\text { How much time (min) h do you spend doing } \\
\text { vigorous-intensity activities at work on a typical } \\
\text { day? [Mean; SD] }\end{array}$} & $\mathrm{N}$ & 130 & 66 & 64 & \multirow[t]{2}{*}{0.176} & & \\
\hline & $\begin{array}{l}\text { [Mean; } \\
\text { SD] }\end{array}$ & $\begin{array}{l}5.11 \\
3.43\end{array}$ & 5,$51 ; 3,76$ & $\begin{array}{l}4.70 \\
3.01\end{array}$ & & & \\
\hline \multicolumn{8}{|l|}{ SPORTS } \\
\hline \multirow{2}{*}{$\begin{array}{l}\text { Do you do any vigorous-intensity sports, fitness } \\
\text { or recreational (leisure) activities that cause } \\
\text { large increases in breathing or heart rate like } \\
\text { [running or football,] for at least } 10 \text { minutes } \\
\text { continuously? (\%) }\end{array}$} & Yes & $\begin{array}{l}57 \\
(24.3)\end{array}$ & 25 (21.9) & $\begin{array}{l}32 \\
(26.4)\end{array}$ & \multirow[t]{2}{*}{0.419} & 0.78 & $\begin{array}{l}{[0.41 ;} \\
1.48]\end{array}$ \\
\hline & No & $\begin{array}{l}178 \\
(75,7)\end{array}$ & $89(78.1)$ & $\begin{array}{l}89 \\
(73.6)\end{array}$ & & & \\
\hline \multirow{2}{*}{$\begin{array}{l}\text { In a typical week, on how many days do you do } \\
\text { vigorous- intensity sports, fitness or recreational } \\
\text { (leisure) activities? [Mean; SD] }\end{array}$} & $\mathrm{N}$ & 58 & 25 & 33 & \multirow[t]{2}{*}{0.415} & & \\
\hline & $\begin{array}{l}\text { [Mean; } \\
\text { SD] }\end{array}$ & $\begin{array}{l}3.36 \\
1.92\end{array}$ & $\begin{array}{l}3.60 \\
2.26\end{array}$ & $\begin{array}{l}3.18 \\
1.63\end{array}$ & & & \\
\hline \multirow{2}{*}{$\begin{array}{l}\text { How much time (minutes) do you spend doing } \\
\text { vigorous-intensity sports, fitness or recreational } \\
\text { activities on a typical day? [Mean; SD] }\end{array}$} & $\mathrm{N}$ & 61 & 25 & 36 & \multirow[t]{2}{*}{0.570} & & \\
\hline & $\begin{array}{l}\text { [Mean; } \\
\text { SD] }\end{array}$ & $\begin{array}{l}2.77 ; \\
2.10\end{array}$ & $\begin{array}{l}2.59 \\
2.07\end{array}$ & $\begin{array}{l}2.90 \\
2.13\end{array}$ & & & \\
\hline \multirow{2}{*}{$\begin{array}{l}\text { In atypical week, on how many days do you } \\
\text { walk or bicycle for at least } 10 \text { minutes } \\
\text { continuously to get to and from places? [Mean; } \\
\text { SD] }\end{array}$} & $\mathrm{N}$ & 165 & 87 & 78 & \multirow[t]{2}{*}{0.006} & & \\
\hline & & $\begin{array}{l}5.04 \\
2.06\end{array}$ & $4.63 ; 2.03$ & $\begin{array}{l}5.50 \\
2.00\end{array}$ & & & \\
\hline
\end{tabular}

\section{Figures}




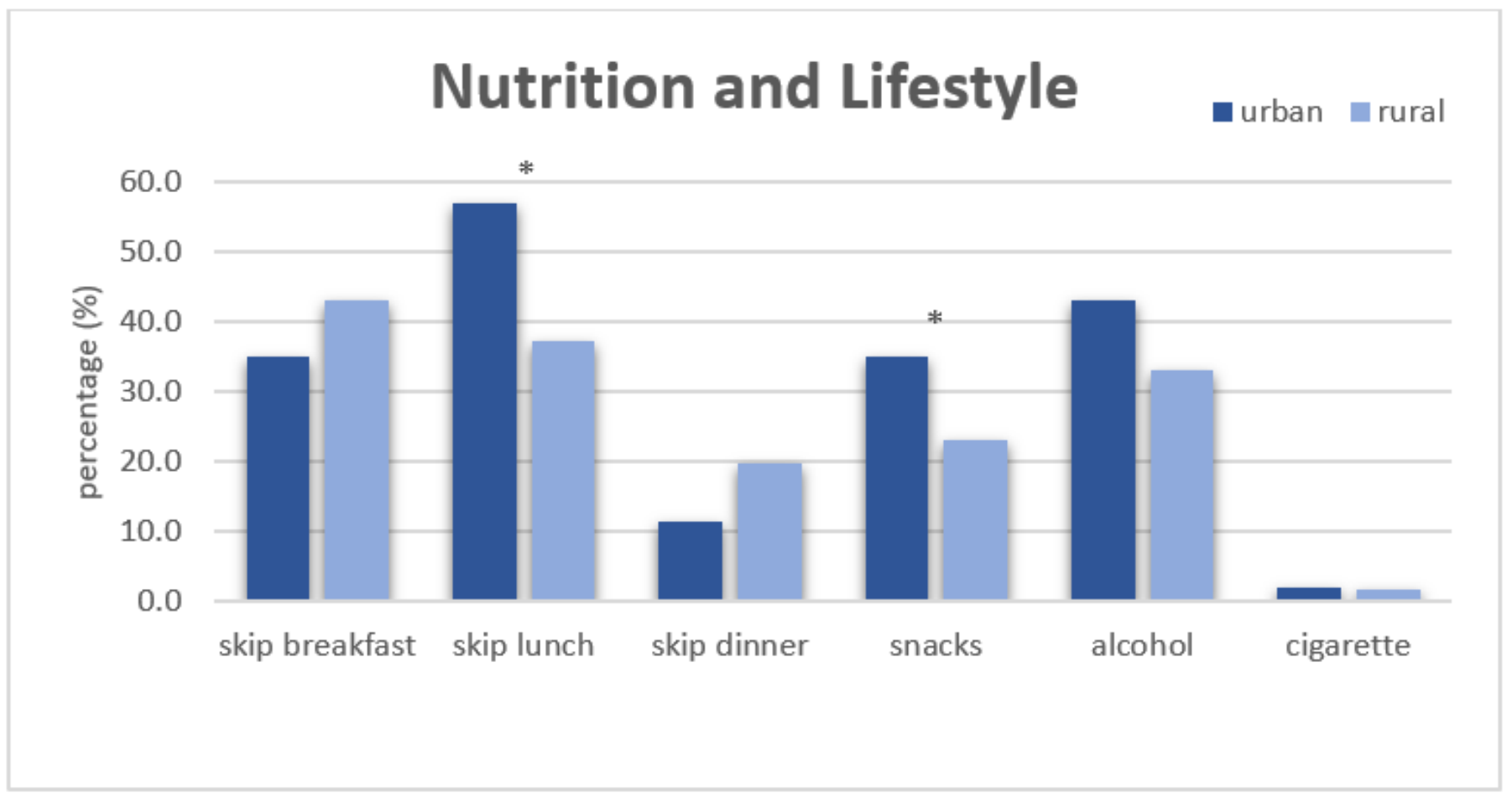

Figure 1

The correlations between nutrition behaviour \& lifestyle and residence are shown in fig.1. 